\title{
EFFECT OF POST-HATCH FEED DEPRIVATION ON FATTY ACID COMPOSITION OF BROILER MEAT
}

\author{
S. Sugiharto, I. Isroli, T. Yudiarti, E. Widiastuti, E. Kusumanti \\ Faculty of Animal and Agricultural Sciences, Diponegoro University, \\ Tembalang Campus, Semarang 50275 - Indonesia \\ Corresponding E-mail: sgh_undip@yahoo.co.id \\ Received October 11, 2015; Accepted November 24, 2015
}

\begin{abstract}
ABSTRAK
Tujuan dari penelitian ini adalah untuk mengevaluasi pengaruh pemuasaan selama 48 jam setelah menetas terhadap komposisi asam lemak pada daging ayam broiler. Sejumlah 60 anak ayam strain Ross umur 1 hari dibagi ke dalam dua kelompok perlakuan, yaitu kelompok anak ayam yang mendapatkan akses terhadap air dan pakan secara ad libitum seketika setelah menetas sampai dengan umur 35 hari dan kelompok ayam yang diberikan pakan 48 jam setelah menetas. Darah untuk analisis kolesterol diperoleh dari ayam umur 34 hari, dan pada umur 36 hari ayam yang sama kemudian disembelih. Sesaat setelah disembelih, daging (tanpa kulit) dari bagian dada, lemak abdomen, jantung dan hati diambil dan ditimbang. Pemuasaan selama 48 jam setelah menetas menyebabkan pertumbuhan ayam menjadi terhambat $(\mathrm{P}<0.05)$, namun tidak berpengaruh terhadap lemak abdomen, komposisi asam lemak pada daging, total kolesterol dalam serum serta berat jantung dan hati ayam broiler $(\mathrm{P}>0.05)$. Dapat disimpulkan bahwa pemberian pakan sesaat setelah ayam menetas merupakan metode yang sangat baik untuk meningkatkan bobot akhir ayam broiler tanpa mempengaruhi kualitas daging ayam broiler.
\end{abstract}

Kata kunci: paska penetasan, pemuasaan, asam lemak, daging, ayam pedaging

\begin{abstract}
The objective of the present study was to investigate the effect of feed deprivation over the first 48 $\mathrm{h}$ post-hatch on the composition of fatty acids in broiler meat. Sixty 1-d-old Ross chicks were divided to two experimental groups, i.e., birds provided access to feed and water ad libitum immediately post-hatch until d 35 and birds deprived from feed but not from water over the first $48 \mathrm{~h}$ post-hatch. Blood for cholesterol analysis was collected on $\mathrm{d} 34$. The same birds were sacrificed on $\mathrm{d} 36$, and immediately breast meat, abdominal fat, heart and liver were collected and weighed. Feed deprivation over the first $48 \mathrm{~h}$ post-hatch retarded $(\mathrm{P}<0.05)$ growth performance of chickens, but had no impact $(\mathrm{P}>0.05)$ on the abdominal fat, fatty acid profile of meat, total serum cholesterol level as well as the weight of heart and liver of broiler. In conclusion, early post-hatch feeding is a beneficial means to enhance the final body weight of broilers without affecting the meat quality.

Keywords: post-hatch, feed deprivation, broiler, fatty acid, meat
\end{abstract}

\section{INTRODUCTION}

The content and composition of fatty acids have profound implications on poultry meat quality (Wood et al., 2003). A number of factors have been reported to influence the fatty acid composition in meat, and that feed restriction/deprivation is one of the most important factors (Więcek et al., 2011). Under practical conditions, the post-hatch chicks are often withheld from feed and water for substantial time during the transportation from the hatchery to the farm (Juul-Madsen et al., 2004). While the post-hatch feed deprivation has been reported to 
impair the growth performance of broiler chickens (Juul-Madsen et al., 2004), early feed restriction indeed produced broiler carcass with lower abdominal fat content which is favourable for the consumers (Zhan et al., 2007). In pigs, feed restriction was associated with a lower proportion of saturated fatty acids (SFAs) and a higher proportion of polyunsaturated fatty acids (PUFAs) in meat (Więcek et al., 2011). The effect of posthatch feed withholding on the fatty acid profile of broiler meat, however, remains less elucidated. Hence, the objective of the present study was to investigate the effect of feed deprivation over the first $48 \mathrm{~h}$ post-hatch on the composition of fatty acids in broiler meat.

\section{MATERIALS AND METHODS}

Sixty male 1-d-old Ross chicks were divided to two groups of feeding times post-hatch, i.e., birds provided access to feed and water ad libitum immediately after hatching until d 35, and birds deprived from feed but not from water over the first $48 \mathrm{~h}$ post-hatch. Within each group, the chicks were randomly allotted into six wire floors pens with five chicks per pen situated in a semi closed house system. The diet was equivalent to commercial chick starter crumbles from $\mathrm{d} 0$ to $\mathrm{d}$ 35 and was similar for the two groups (Table 1).

One bird from each pen was blood sampled from its wing vein on $\mathrm{d} 34$. The total serum cholesterol level was determined based on the enzymatic method using Auto analyser-Advia 1650. The same birds were sacrificed on d 36 and immediately breast meat (skinless), abdominal fat, heart and liver were collected and weighed. The fatty acids composition of meat was determined based on Bligh and Dyer (1959) using HP-6890 gas chromatograph equipped with an autosampler, FID and fused-silica capillary column $(30 \mathrm{~m} \times$ $0.25 \mathrm{~mm} \times 0.2 \mu \mathrm{m}$ film thickness). A sample (1 $\mu \mathrm{L}$ ) was injected with helium as a carrier gas onto the column programmed for ramped oven temperatures (initial temperature was $110^{\circ} \mathrm{C}$ held for $1.0 \mathrm{~min}$, then ramped at $15^{\circ} \mathrm{C} / \mathrm{min}$ to $190^{\circ} \mathrm{C}$ and held for $5 \mathrm{~min}$, then ramped at $5^{\circ} \mathrm{C} / \mathrm{min}$ to $230^{\circ} \mathrm{C}$ and held for $5 \mathrm{~min}$ ). Inlet and detector temperatures were held at $220^{\circ} \mathrm{C}$. Peak areas and percentages were calculated using a HewlettPackard ChemStation software. Fatty acids methyl esters were identified by comparison with retention times of authentic standard.

The data on fatty acids composition of breast meat, total serum cholesterol, the weight of heart
Table 1. Composition of the Experimental Diet

\begin{tabular}{lc}
\hline Ingredients & $\begin{array}{c}\text { Composition } \\
(\mathrm{g} / \mathrm{kg})\end{array}$ \\
\hline Yellow corn & 56.2 \\
Soy bean meal (SBM) & 24.5 \\
Meat bone meal (MBM) & 6.00 \\
Corn gluten meal (CGM) & 3.00 \\
Palm kernel meal (PKM) & 1.50 \\
Distiller dried grain soluble & \\
(DDGS) & 0.90 \\
Top mix* & 7.87 \\
Calculated nutrient content: & \\
- Metabolisable energy (MJ/100kg) & 1,243 \\
- Crude protein (N×6.25) & 20.8 \\
- Total fat (\%) & 5.92 \\
\hline
\end{tabular}

*Each kg Top mix contained vitamin A (1,200,000 IU), vitamin $\mathrm{D}_{3}(200,000 \mathrm{IU})$, vitamin $\mathrm{E}$ (800 IU), vitamin B1 (200 mg), vitamin B2 (500 mg), vitamin B6 (50 $\mathrm{mg})$, vitamin B12 (1,200 $\mu \mathrm{g})$, vitamin $\mathrm{K}(200 \mathrm{mg})$, vitamin $\mathrm{C}(2,500 \mathrm{mg})$, Ca D-pantothenate $(600 \mathrm{mg})$, niacin $(4,000 \mathrm{mg})$, manganese $(1,200 \mathrm{mg})$, iron $(2000$ $\mathrm{mg})$, iodine $(20 \mathrm{mg})$, zinc $(10,000 \mathrm{mg})$, cobalt $(20 \mathrm{mg})$, copper $(400 \mathrm{mg})$, santoquin $(1,000 \mathrm{mg})$, zinc bacitracin $(21,000 \mathrm{mg})$, choline chloride $(1,000 \mathrm{mg})$, methionine $(3,000)$ and lysine $(3,000 \mathrm{mg})$

and liver were analyzed with paired-samples t-test procedure. A p-value of less than 0.05 was considered statistically significant. The data were presented as means \pm SEM.

\section{RESULTS AND DISCUSSION}

While withholding the chicks from feed over the first $48 \mathrm{~h}$ post-hatch resulted in a lower $(\mathrm{P}<0.05)$ final body weight $(1,935 \mathrm{~g}$ versus 2,019 $\mathrm{g})$, this treatment did not influence $(\mathrm{P}>0.05)$ the abdominal fat content (percentage to live body weight, $1.6 \%$ versus $1.9 \%$ ) of broiler in the present study. A similar result was reported by ElHusseiny et al. (2008) in broiler deprived from feed during the first $48 \mathrm{~h}$ post-hatch. It has been reported in pigs that SFAs and monounsaturated fatty acids (MUFAs) content in pork meat decrease with decreasing fatness, leading to a 
Table 2. Fatty Acid Composition (mg/100g) of Breast Meat

\begin{tabular}{lcccc}
\hline Fatty acids & $\begin{array}{c}\text { Feed deprived- } \\
\text { birds }\end{array}$ & \multicolumn{2}{c}{$\begin{array}{c}\text { Undeprived- } \\
\text { birds }\end{array}$} \\
\hline C14:0 & $4.90 \pm 1.45$ & $4.11 \pm 1.76$ \\
C16:0 & $192 \quad \pm 24.20$ & $199 \quad \pm 22.40$ \\
C18:0 & $61.10 \pm 5.10$ & $63.50 \pm 5.67$ \\
C16:1n-7 & $38.90 \pm 9.61$ & $40.00 \pm 7.62$ \\
C18:1n-9 & $263 \quad \pm 40.20$ & $278 \quad \pm 40.30$ \\
C18:1n-7 & $21.10 \pm 1.89$ & $27.60 \pm 4.03$ \\
C18:3n-3 & $7.51 \pm 1.38$ & $7.97 \pm 1.43$ \\
C20:5n-3 & $1.96 \pm 0.07$ & $2.29 \pm 0.16$ \\
C22:5n-3 & $3.66 \pm 0.36$ & $3.24 \pm 0.53$ \\
C22:6n-3 & $3.12 \pm 0.33$ & $2.92 \pm 0.34$ \\
C18:2n-6 & $170 \pm 18.60$ & $179 \pm 19.10$ \\
C18:3n-6 & $1.51 \pm 0.25$ & $1.66 \pm 0.18$ \\
C20:3n-6 & $9.79 \pm 0.86$ & $10.10 \pm 0.64$ \\
C20:4n-6 & $33.04 \pm 2.26$ & $31.20 \pm 1.65$ \\
C22:5n-6 & $9.30 \pm 0.74$ & $8.54 \pm 1.01$ \\
\hline
\end{tabular}

Table 3. Total Serum Cholesterol $(\mathrm{mmol} / \mathrm{L})$ and Percentage of Heart or Liver to Live Body Weight (\%)

\begin{tabular}{lcc}
\hline & $\begin{array}{c}\text { Feed } \\
\text { deprived- } \\
\text { birds }\end{array}$ & $\begin{array}{c}\text { Undeprived } \\
\text {-birds }\end{array}$ \\
\hline Serum total cholesterol & $3.26 \pm 0.14$ & $3.53 \pm 0.22$ \\
Heart weight & $0.55 \pm 0.04$ & $0.52 \pm 0.01$ \\
Liver weight & $2.34 \pm 0.12$ & $2.18 \pm 0.15$ \\
\hline
\end{tabular}

higher relative content of PUFAs and the resultant increase in the PUFAs/SFAs ratio (Więcek et al., 2011). Consistent with the abdominal fat content, the composition of fatty acids in breast meat did not differ between the post-hatch feed deprivedand undeprived-broilers in the current study (Table 2). Gonzalez et al. (2011) reported that early feeding $(\sim 5 \mathrm{~h}$ versus $48 \mathrm{~h}$ post-hatch) increased linoleic and arachidonic acids in the plasma and oleic acid in the liver, and reduced arachidonic acid in the liver. However, the treatment did not affect the composition of fatty acid in the spleen of broilers. The low total fat content in the chicken breasts when compared with that in the other organs such as liver (Santoso, 2002) may explain the discrepancy between the current result and that of reported by the previous authors.

Feed restriction/deprivation has been known to affect the cholesterol content in broiler chickens. Santoso (2001) reported that free cholesterol content in the liver and carcass was decreased by an early feed restriction. Unlike the latter work, there was no difference $(\mathrm{P}>0.05)$ in the total serum cholesterol between the post-hatch feed deprived- and undeprived-broilers in the present study (Table 3). The response of cholesterol levels to feed restriction/deprivation seems to depend on the time of treatments (feed deprivation) applied. Goodridge (1968) reported that the response of cholesterol synthesis to fasting and feeding differed between older and the newly hatched chicks. Whereas there is only a small increase in the rate of cholesterol synthesis when 1-d-old chicks are fed, the substantial increase occurs after the chicks are 5-d-old. Hence, fasting over the first $48 \mathrm{~h}$ post-hatch or immediate feeding post-hatch had no significant influence on the total serum cholesterol level of broilers.

It has been known that feed deprivation followed by realimentation leads to the change in metabolic rate, which may in turn alter the weight of the supply organs such as heart and liver. In the current study, feed deprivation over the first $48 \mathrm{~h}$ post-hatch did not alter $(\mathrm{P}>0.05)$ the weight of heart and liver of broilers measured at d 36 (Table $3)$. This result was in agreement with Mahmood et al. (2007) reporting that the relative weight of heart and liver of broiler on d 42 remained unaffected by feed restriction during the starter phase.

\section{CONCLUSION}

Feed deprivation over the first $48 \mathrm{~h}$ posthatch retarded growth performance of chickens, but had no impact on the abdominal fat, fatty acid profile of meat, serum cholesterol level as well as the weight of heart and liver of broiler. Early posthatch feeding is a beneficial means to enhance the final body weight of birds without affecting the meat quality. 


\section{REFERENCES}

Bligh, E.G. and W.J. Dyer 1959. A rapid method of total lipid extraction and purification. Can. J. Biochem. Physiol. 37:911-917.

El-Husseiny, O.M., S.A. El-Wafa, and H.M.A. ElKomy. 2008. Influence of fasting or early feeding on broiler performance. Int. J. Poult. Sci. 7:263-271.

Gonzalez, D., D.J. Mustacich, M.G. Traber and G. Cherian. 2011. Early feeding and dietary lipids affect broiler tissue fatty acids, vitamin E status, and cyclooxygenase-2 protein expression upon lipopolysaccharide challenge. 90:2790-2800.

Goodridge, A.G. 1968. The effect of starvation and starvation followed by feeding on enzyme activity and the metabolism of [U$\left.{ }^{14} \mathrm{C}\right]$ glucose in liver from growing chicks. Biochem. J. 108:667-673.

Juul-Madsen, H.R., G. Su and P. Sorensen. 2004. Influence of early or late start of first feeding on growth and immune phenotype of broilers. Br. Poult. Sci. 45:210-222.

Mahmood, S., S. Mehmood, F. Ahmad, A. Masood and R. Kausar. 2007. Effect of feed restriction during starter phase on subsequent growth performance, dressing percentage, relative organ weights and immune response of broiler. Pak. Vet. J. 27:137-141.

Santoso, U. 2001. Effect of early feed restriction and high-fat realimentation diet on growth and fat accumulation in broiler chicks. Veteriner. 8:19-23.

Santoso, U. 2002. Effects of early feed restriction on breast and leg meat composition and plasma lipid concentration in unsexed broiler chickens reared in cages. Asian-Aust. J. Anim. Sci. 15:1475-1481.

Więcek, J., A. Rekiel, M. Batorska and J. Skomia. 2011. Effect of restricted feeding and realimentation periods on pork quality and fatty acid profile of M. longissimus thoracis. Meat Sci. 87:244-249.

Wood, J.D., R.I. Richardson, G.R. Nute, A.V. Fisher, M.M. Campo, E. Kasapidou, P.R. Sheard and M. Enser. 2003. Effects of fatty acids on meat quality: a review. Meat Sci. 66:21-32.

Zhan, X.A., M. Wang, H. Ren, R.Q. Zhao, J.X. Li, Z.L. Tan. 2007. Effect of early feed restriction on metabolic programming and compensatory growth in broiler chickens. Poult. Sci. 86:654-660. 